\title{
Journal of Food and Dairy Sciences
}

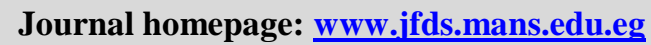

Available online at: www.jfds.journals.ekb.eg

\section{Preparation of Low Fat Probiotic Yoghurt Supplemented with Pomegranate Pomace Powder as Source of Antioxidant Dietary Fibers}

\section{Fatema H. Abd El Moneem ${ }^{1}$; Ahdab A. Elmaadawy 1; Z. S. Mohamed ${ }^{1}$ and E. H. Atwaa ${ }^{2 *}$}

${ }^{1}$ Department of Home Economics, Faculty of Specific Education, Zagazig University, Egypt.

${ }^{2}$ Food Science department, Faculty of Agriculture, Zagazig University, Egypt

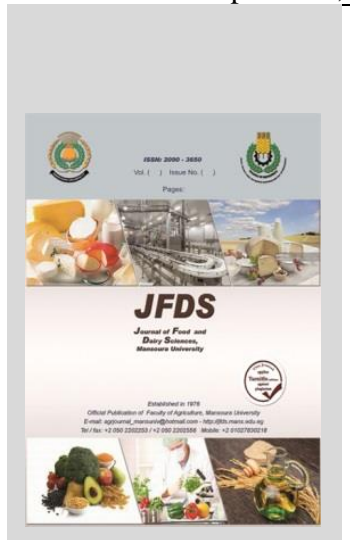

ABSTRACT

The effect of fortification of low fat milk with pomegranate pomace powder on the chemical, rheological, antioxidant and sensory properties of low fat (1\% fat) probiotic yoghurt was studied. Pomegranate pomace powder was added to low fat milk yoghurt at levels of 1 , and $2 \%$, low fat yoghurt was analyzed when fresh and during the passage of 5,10 and 15 days of storage at the temperature of the refrigerator. The results showed that fortification of reduced-fat milk used in the manufacture of probiotic yoghurt significantly affected the chemical composition of the resulting yoghurt as it increased the contents of total solids, protein, ash, dietary fiber and phenolic, $\mathrm{pH}$ and viscosity values, and these increases were proportional to the supplementation ratio. While the values of acidity and whey separation decreased as a supplementation ratio increased. Supplementation of reduced fat yoghurt with the pomegranate pomace powder improved the viability of probiotic starter culture. Low fat yoghurt containing $2 \%$ pomegranate pomace powder had the highest scores of the sensory evaluation was gained in the presence of $2 \%$ pomegranate pomace powder, compared to other low fat yoghurt treatments .Through the results, it can be recommended to fortify the low-fat milk used in the manufacture of yoghurt with pomegranate pulp powder by $2 \%$, as this fortification improved the chemical, rheological, antioxidant and sensory properties of the resulting low-fat yoghurt.
\end{abstract}

Keywords: probiotic yoghurt, pomegranate pomace , physicochemical, microbiological, sensory properties.

\section{INTRODUCTION}

Yogurt is produced as a result of the fermentation of milk by a starter of lactic acid bacteria such as (Lactobacillus delbrueckii ssp. bulgaricus and Streptococcus salivarius ssp. thermophilus). Yogurt is better digestible than milk and provides the human body with many health benefits through prebiotic and probiotic bacteria. (Dabija et al., 2018 and Pakseresht et al, 2019).

During the last two decades, consumers have trend to use of reduced fat dairy products (Ozer et al. 2007) but the functional role of fat in fermented milk makes this difficult. The fat content of yoghurt causes enhancement of viscosity and decreased of whey syneresis (Ramchandran and Shah 2008). Fat also improves the sensory properties in yoghurt (Pakseresht et al, 2019). However, since using stabilizers such as natural or synthetic gums in fermented milk production is not allowed in many countries, therefore alternative methods should be used to obtain an appropriate consistency of low-fat dairy products (Ozer et al. 2007). One of the advantages of using dietary fiber to fortify dairy products is that it increases the content of dietary fiber in the product, acts as a substitute for fat and solves some technological problems, probiotic or synbiotic effect, bulking agent or micronutrient premixes, (Arora et al, 2015).

The importance of probiotic containing products for maintaining health and well-being is becoming a key factor affecting consumer choice, resulting in raped growth and expansion in the market for such products. The majority of probiotic food already on the market such as, fermented milks and yoghurt are fresh products which consumed within days or weeks of manufacture. The potential health promoting effects of dairy products which incorporate probiotic organisms such as lactobacillus and Bifidobacterium spp has stimulated a major research effort in recent years (Baú et al ,2014 :Atwaa et al, 2020). The general trend is increasing towards the use of by-products such as some agricultural crop residues as by-products in food processing around the world (Abd Rabo et al., 2019).

Fruit and vegetable wastes are naturally rich with bioactive compounds like minerals, vitamins, antioxidants, phenolic compounds and fiber. The peels, seeds and other wastes of numerous fruit can be used as functional foods (Sagar et al, 2018).As a result of the food insecurity associated with malnutrition and the possibility of infectious diseases. The consumer has taken great interest in the health and nutritional components of diets and has identified good strategies to tackle malnutrition and alleviate the various health disorders associated with it. (Akhtar et al., 2013).

During the pomegranate juice manufacture, significant quantities of pomace are produced, and they account for about $50 \%$ on average fresh weight. In recent years, attention has been paid to the inedible portions of pomegranate (Hasnaoui et al. 2014), mainly due to their high phenolic and flavonoids content. In this way, the reuse of pomegranate pomace obtained from the juice manufacture to take advantage of the vast amount of beneficial compounds, can be of significance in products that require viscosity development, antibacterial agents, hydration, and freshness preservation in foods products (Gullon et al., 2016; Akhtar et al., 2015). Moreover, pomegranate pomace can be used as a 
antimicrobial against pathogenic bacteria (Kang and Song 2017).

This study aims to studying the effect of supplementation low fat probiotic yoghurt with pomegranate pomace powder on its rheological, microbiological and sensory characteristics.

\section{MATERIALS AND METHODS}

Standardized milk containing 3\% fat was obtained from Faculty of Agriculture, Zagazig University, Egypt. Pomegranate was purchased from local market. Pomegranate pomace was obtained after extraction of juice, washed and dried in thermostatically controlled oven with air fan at 40$45^{\circ} \mathrm{C}$ for $48 \mathrm{hrs}$., milled using a laboratory disc to pass through a $40 \mathrm{mesh} / \mathrm{inch}$ sieve, stored at $3-4^{\circ} \mathrm{C}$ until used.

Probiotic starter culture (ABT-5) containing Streptococcus thermophilus, Lactobacillus acidophilus and Bifidobacterium bifidum were obtained from the Microbiological Resources Center (MIRCEN), Faculty of Agric. Aim Shams Univ., Egypt. Gallic acid, 1, 1-diphenyl-2picrylhydrazyl (DPPH), and other chemicals and reagents were purchased form Sigma-Aldrich (MO,IL USA) .

Total phenolic content (TPC) was determined according to Kaur and Kapoor (2002) .

Antioxidant activity was evaluated by the DPPH assay according to Brand Williams et al,(1995).

Making low fat yoghurt: milk containing 3\% fat was used in the preparation of probioitc yoghurt and served as a control (C). Low fat buffaloe's milk having $1 \%$ fat was divided into 3 portions. The first portion was left without additive as a control (C1), pomegranate pomace powder (PPP) was added to the other two portions at the rate of 1 and $2 \%$ (T1, and T2). All milk treatments were heated to $90{ }^{\circ} \mathrm{C}$ for 15 min., then, cooled to $42 \pm 1{ }^{\circ} \mathrm{C}$, inoculated with $2 \%$ of yoghurt probiotic cultures, filled in plastic cups and incubated at $42{ }^{\circ} \mathrm{C}$ until a uniform coagulation was obtained. The probiotic yoghurt samples from all treatments were stored at $5 \pm 1{ }^{\circ} \mathrm{C}$ and analyzed when fresh and after 5, 10 and 15 days.

Methods of AOAC (2016) were used to determine fat, total protein, total solids, fiber contents and titratable acidity of yoghurt treatments. A laboratory $\mathrm{pH}$ meter with glass

electrode (HANNA, Instrument, Portugal) was used to measure changes in $\mathrm{pH}$ values of yoghurt treatments.

Whey syneresis and viscosity of yoghurt treatments were measured according to the method of Aryana (2003).

S. thermophilus, L. acidophilus and Bifidobacterium $B B-12$ count were determined previously described by Martin-Diana et al. (2003). Total bacterial count was determined according to Houghtby et al., (1992). Counts of coliforms, bacteria, yeasts and moulds were determined according to Marshall (1992).

The sensory properties of yoghurt samples were assessed by 10 panel members of the Dairy Sci., Dep., Fac. Agric., Zagazig, Univ. They evaluated $20 \mathrm{~g}$ portions of each yoghurt sample and used a quality rating score card for evaluation of color $\&$ appearance ( 9 points), flavor ( 9 points), body \& texture ( 9 points), consistency ( 9 points) and overall acceptability as described by Nelson and Trout (1981).

Statistical analysis of the obtained results was carried using analysis of variance as reported by McClave \& Benson (1991).

\section{RESULTS AND DISCUSSION}

Chemical and phenolic content of pomegranate pomace powder

Chemical composition of pomegranate pomace powder (PPP) is illustrated in Table (1). Moisture, protein, fat, ash and fiber contents of pomegranate pomace powder (PPP) were $(8.40,8.60,1.80,8.90$ and $31.70 \mathrm{~g} / 100 \mathrm{~g}$, respectively. This result agrees with Cano-Lamadrid et al, (2018).

Data in Table (2) reveal that, the TPC of PPP were $590.30 \mathrm{mg} / 100 \mathrm{~g}$. While the radical scavenging activity (RSA \%) was 90.60. Similar results were obtained by CanoLamadrid et al, (2018).

Table 1. Chemical composition, total phenolic contents and radical scavenging activity of pomegranate pomace powder

\begin{tabular}{lc}
\hline Chemical composition & Pomegranate pomace powder \\
\hline Moisture $(\%)$ & $8.40 \pm 0.09$ \\
Total protein $(\%)$ & $8.60 \pm 0.9$ \\
Fat $(\%)$ & $1.80 \pm 0.04$ \\
Ash $(\%)$ & $8.90 \pm 0.7$ \\
Fiber $(\%)$ & $31.70 \pm 1.2$ \\
Total phenolic content(mg/100g) & $09 .,+\cdot \pm 9.6$ \\
Radical scavenging activity $(\%)$ & $90.60 \pm 2.5$ \\
\hline
\end{tabular}

Table 2. Effect of supplementation low fat probiotic yoghurt with pomegranate pomace powder on chemical composition during storage at refrigerator temperature for 15 day

\begin{tabular}{|c|c|c|c|c|c|}
\hline \multirow{2}{*}{$\begin{array}{l}\text { Components } \\
(\%)\end{array}$} & \multirow{2}{*}{$\begin{array}{c}\text { Storage period } \\
\text { (Day) }\end{array}$} & \multicolumn{4}{|c|}{ Treatments } \\
\hline & & $\mathbf{C}$ & $\mathbf{C}_{1}$ & $\mathbf{T}_{1}$ & $\mathbf{T}_{2}$ \\
\hline \multirow{4}{*}{ TS } & Fresh & $12.26 \pm 0.50^{\mathrm{a}}$ & $10.32 \pm 0.44^{\mathrm{c}}$ & $11.08 \pm 0.52^{\mathrm{b}}$ & $11.94 \pm 0.41^{b}$ \\
\hline & 5 & $12.40 \pm 0.48^{\mathrm{a}}$ & $11.06 \pm 0.30^{c}$ & $11.66 \pm 0.32^{b}$ & $12.06 \pm 0.42^{\mathrm{ab}}$ \\
\hline & 10 & $13.05 \pm 0.42^{\mathrm{a}}$ & $11.18 \pm 0.40^{c}$ & $12.04 \pm 0.38^{b}$ & $12.50 \pm 0.35^{\mathrm{ab}}$ \\
\hline & 15 & $13.48 \pm 0.40^{\mathrm{a}}$ & $11.84 \pm 0.32^{\mathrm{c}}$ & $12.42 \pm 0.44 b$ & $13.03 \pm 0.42^{\mathrm{ab}}$ \\
\hline \multirow{4}{*}{ Fat } & Fresh & $3.10 \pm 0.14^{\mathrm{a}}$ & $1.20 \pm 0.07^{b}$ & $1.24 \pm 0.05^{\mathrm{b}}$ & $1.32 \pm 0.04^{\mathrm{b}}$ \\
\hline & 5 & $3.20 \pm 0.12^{\mathrm{a}}$ & $1.30 \pm 0.10^{b}$ & $1.34 \pm 0.11^{b}$ & $1.38 \pm 0.09 b$ \\
\hline & 10 & $3.40 \pm 0.10^{\mathrm{a}}$ & $1.58 \pm 0.18^{b}$ & $1.60 \pm 0.16^{\mathrm{b}}$ & $1.64 \pm 0.12 b$ \\
\hline & 15 & $3.65 \pm 0.14^{\mathrm{a}}$ & $1.90 \pm 0.22^{b}$ & $1.94 \pm 0.18^{b}$ & $1.98 \pm 0.12^{\mathrm{b}}$ \\
\hline \multirow{4}{*}{ Protein } & Fresh & $3.52 \pm 0.18^{c}$ & $3.87 \pm 0.14^{b}$ & $3.95 \pm 0.12^{b}$ & $4.16 \pm 0.14^{\mathrm{ab}}$ \\
\hline & 5 & $3.64 \pm 0.22^{c}$ & $4.12 \pm 0.16^{\mathrm{b}}$ & $4.36 \pm 0.12^{b}$ & $4.54 \pm 0.12^{\mathrm{ab}}$ \\
\hline & 10 & $3.85 \pm 0.25^{\mathrm{c}}$ & 4. $34 \pm 0.14^{b}$ & $4.52 \pm 0.15^{\mathrm{b}}$ & $4.70 \pm 0.14^{\mathrm{ab}}$ \\
\hline & 15 & $4.10 \pm 0.28^{c}$ & $4.50 \pm 0.22^{\mathrm{b}}$ & $4.68 \pm 0.20^{b}$ & 4. $86 \pm 0.18^{a b}$ \\
\hline \multirow{4}{*}{ Fiber } & Fresh & - & - & $0.45 \pm 0.01^{\mathrm{c}}$ & $0.92 \pm 0.02^{b}$ \\
\hline & 5 & -- & - & $0.80 \pm 0.05^{c}$ & $1.56 \pm 0.03^{b}$ \\
\hline & 10 & - & - & $1.00 \pm 0.06^{\mathrm{c}}$ & $1.90 \pm 0.05^{\mathrm{b}}$ \\
\hline & 15 & - & - & $1.30 \pm 0.04^{\mathrm{c}}$ & $2.14 \pm 0.04^{\mathrm{b}}$ \\
\hline
\end{tabular}

* Values (means \pm SD) with different superscript letters are statistically significantly different $(P \leq 0.05)$

C: Control full fat yoghurt ( $3 \%$ fat ) $\quad C_{1}$ : Control low fat yoghurt (1\% fat).

$T_{1}$ : Low fat yoghurt containing $1 \%$ pomegranate pomace powder $\quad T_{2}$ : Low fat yoghurt containing $2 \%$ pomegranate pomace powder 
Effect of supplementation low fat probiotic yoghurt with pomegranate pomace powder on chemical composition:

Results illustrated in Table (2) show that the highest total solids (TS) were observed in full fat yoghurt (3\% fat) compared with reduced fat yoghurt treatments. Supplementation low fat yoghurt with PPP increased gradually the TS contents with increase the supplementation ratios.

With storage period progressed the TS content of all yoghurt treatments were increased.

On the other said the lowest protein content was observed in control full fat yoghurt (C) compared to low fat treatments. Supplementation low fat yoghurt with PPP increased slightly increased protein content with increase the supplementation ratios. With the storage period progressed total protein content is slightly increased for all yogurt treatments.

Regarding fat content, addition of PPP to reduced fat milk did not affect the fat content of reduced fat yoghurt treatments, and this might be due to the low fat content of PPP (Cano-Lamadrid et al., 2018). With respect to fiber content supplementation low fat yoghurt with PPP increased fiber content and these increments were proportional to the supplementation ratio. These results are the line with those reported by Hasani et al., (2017) and Atwaa et al,(2020).

Effect of supplementation low fat probiotic yoghurt with pomegranate pomace powder on acidity, $\mathrm{pH}$, whey syneresis and viscosity:

Data obtained in Table (3) reveal that control low fat yoghurt contained the highest acidity, compared with full fat yoghurt, supplementation of low fat yoghurt with PPP decreased the acidity, and the decrease was proportional to the concentration of PPP used. With storage period progressed the acidity of all yoghurt treatments were increased

The $\mathrm{pH}$ values of the PPP fortified yoghurt samples took an opposite direction to the acidity values. Similar results were reported by Al-hamdani et al (2015),Hasani et al., (2017) and Atwaa et al, (2020).

The supplementation of low fat yoghurt with PPP significantly decreased whey separation, compared with control low fat yoghurt, and this decrement was proportional to the level of PPP used. .Control low fat yoghurt had the highest whey separation compared to other treatments. As the storage period increased, the rate of syneresis increased for all yoghurt treatments. This may be due to the high content of dietary fiber in PPP, which has a great ability to water holding capacity of resultant curd (Cano-Lamadrid et al., 2018).

Results in Table (3) also show that control low fat yoghurt (C1) was significantly lower viscosity, compared with full fat and supplemented low fat yoghurt. Supplementation of low fat yoghurt with PPP increased the viscosity of reduced fat yoghurt. These increases were proportional to the PPP supplementation ratio. With the storage period progressed the viscosity of all yoghurt treatments is increased. The current data align with Dabija et al, (2018) and Atwaa et al, 2020) .

Effect of supplementation low fat probiotic yoghurt with pomegranate pomace powder on antioxidant activity:

Data presented in Table 4 show that TPC (mg /100 g) and RSA \% of reduced fat yoghurt enriched with PPP increased by increasing the supplementation ratio. Total phenolic content and radical scavenging activity of all samples decreased with storage period progressed. These results have been confirmed by Jambi (2018) and Atwaa et al, (2020).

Table 3. Effect of supplementation low fat probiotic yoghurt with pomegranate pomace powder on acidity, pH, whey syneresis and viscosity during storage at refrigerator temperature for 15 day

\begin{tabular}{|c|c|c|c|c|c|}
\hline \multirow{2}{*}{ Parameters } & \multirow{2}{*}{$\begin{array}{c}\text { Storage period } \\
\text { (Day) }\end{array}$} & \multicolumn{4}{|c|}{ Treatments } \\
\hline & & $\mathbf{C}$ & C1 & T1 & T2 \\
\hline \multirow{4}{*}{ Acidity $\%$} & Fresh & $0.82 \pm 0.04 \mathrm{ab}$ & $0.85 \pm 0.02 \mathrm{a}$ & $0.80 \pm 0.05 b$ & $0.75 \pm 0.07 \mathrm{c}$ \\
\hline & 5 & $0.90 \pm 0.05 \mathrm{ab}$ & $0.94 \pm 0.02 \mathrm{a}$ & $0.85 \pm 0.04 b$ & $0.82 \pm 0.06 b c$ \\
\hline & 10 & $1.08 \pm 0.09 b$ & $1.17 \pm 0.05 \mathrm{a}$ & $0.96 \pm 0.07 \mathrm{c}$ & $0.90 \pm 0.10 \mathrm{~cd}$ \\
\hline & 15 & $1.20 \pm 0.11 \mathrm{~b}$ & $1.28 \pm 0.09 \mathrm{a}$ & $1.05 \pm 0.08 \mathrm{c}$ & $0.95 \pm 0.07 \mathrm{~d}$ \\
\hline \multirow{4}{*}{$\mathrm{pH}$} & Fresh & $4.64 \pm 0.05 b$ & $4.30 \pm 0.08 \mathrm{c}$ & $4.62 \pm 0.06 \mathrm{~b}$ & $4.66 \pm 0.04 a$ \\
\hline & 5 & $4.55 \pm 0.03 b$ & $4.10 \pm 0.06 \mathrm{c}$ & $4.58 \pm 0.05 b$ & $4.75 \pm 0.02 \mathrm{a}$ \\
\hline & 10 & $4.48 \pm 0.07 b$ & $3.96 \pm 0.09 c$ & 4. $52 \pm 0.05 b$ & $4.60 \pm 0.04 \mathrm{a}$ \\
\hline & 15 & $4.35 \pm 0.09 \mathrm{~b}$ & $3.72 \pm 0.10 \mathrm{c}$ & $4.40 \pm 0.07 \mathrm{~b}$ & $4.52 \pm 0.05 \mathrm{a}$ \\
\hline \multirow{4}{*}{$\begin{array}{l}\text { Whey syneresis } \\
(\mathrm{ml} / 100 \mathrm{gm}\end{array}$} & Fresh & $23.00 \pm 1.22 \mathrm{~d}$ & $32.00 \pm 1.18 \mathrm{a}$ & $30.00 \pm 1.24 b$ & $27.00 \pm 1.24 \mathrm{c}$ \\
\hline & 5 & $25.00 \pm 1.18 \mathrm{~d}$ & $36.00 \pm 1.32 \mathrm{a}$ & $33.00 \pm 1.18 b$ & $30.00 \pm 1.25 \mathrm{c}$ \\
\hline & 10 & $29.00 \pm 1.24 \mathrm{~d}$ & $40.00 \pm 1.18 \mathrm{a}$ & $35.00 \pm 1.26 \mathrm{~b}$ & $34.00 \pm 1.32 \mathrm{c}$ \\
\hline & 15 & $31.00 \pm 1.14 \mathrm{~d}$ & $43.00 \pm 1.26 \mathrm{a}$ & $40.00 \pm 1.22 \mathrm{~b}$ & $36.00 \pm 1.34 \mathrm{c}$ \\
\hline \multirow{4}{*}{$\begin{array}{l}\text { Viscosity } \\
\text { (C. P.S.) }\end{array}$} & Fresh & $5510 \pm 112 \mathrm{a}$ & $4310 \pm 77.0 \mathrm{~d}$ & $4470 \pm 90.0 \mathrm{c}$ & $4710 \pm 100.0 \mathrm{~b}$ \\
\hline & 5 & $5600 \pm 124 a$ & $4390 \pm 94.0 \mathrm{~d}$ & $4500 \pm 95.0 \mathrm{c}$ & $4760 \pm 114.0 \mathrm{~b}$ \\
\hline & 10 & $5620 \pm 136 a$ & $4420 \pm 86.0 \mathrm{~d}$ & $4550 \pm 85.0 \mathrm{c}$ & $4910 \pm 120.0 \mathrm{~b}$ \\
\hline & 15 & $5690 \pm 144 a$ & $4500 \pm 95.0 \mathrm{~d}$ & $4610 \pm 90.0 \mathrm{c}$ & $4980 \pm 140.0 \mathrm{~b}$ \\
\hline
\end{tabular}

* Values (means \pm SD) with different superscript letters are statistically significantly different $(P \leq 0.05)$.

Table 4. Effect of supplementation low fat probiotic yoghurt with pomegranate pomace powder on antioxidant activity during storage at refrigerator temperature for 15 day

\begin{tabular}{|c|c|c|c|c|c|}
\hline \multirow{2}{*}{ Parameters } & \multirow{2}{*}{$\begin{array}{c}\text { Storage period } \\
\text { (Day) }\end{array}$} & \multicolumn{4}{|c|}{ Treatments } \\
\hline & & $\mathbf{C}$ & $\mathbf{C}_{1}$ & $\mathbf{T}_{1}$ & $\mathbf{T}_{2}$ \\
\hline \multirow{4}{*}{$\begin{array}{l}\text { Total phenolic content } \\
(\mathrm{mg} / 100 \mathrm{~g})\end{array}$} & Fresh & $60.30 \pm 1.32^{\mathrm{c}}$ & $58.20 \pm 1.26^{c}$ & $66.40 \pm 1.68^{b}$ & $72.50 \pm 1.55^{\mathrm{a}}$ \\
\hline & 5 & $52.70 \pm 1.46^{\mathrm{c}}$ & $50.70 \pm 1.13^{c}$ & $57.20 \pm 1.75^{b}$ & $63.10 \pm 1.62^{\mathrm{a}}$ \\
\hline & 10 & $46.50 \pm 1.44^{\mathrm{c}}$ & $45.30 \pm 1.25^{\mathrm{c}}$ & $50.80 \pm 1.82^{b}$ & $56.20 \pm 1.73^{a}$ \\
\hline & 15 & $40.20 \pm 1.55^{\mathrm{c}}$ & $48.80 \pm 1.22^{c}$ & $46.50 \pm 1.84^{b}$ & $51.40 \pm 1.76^{\mathrm{a}}$ \\
\hline \multirow{4}{*}{$\begin{array}{l}\text { Radical scavenging } \\
\text { activity } \\
\text { RSA \% }\end{array}$} & Fresh & $20.30 \pm 1.20^{c}$ & $19.70 \pm 1.28^{c}$ & $32.40 \pm 1.14^{\mathrm{b}}$ & $40.20 \pm 1.10^{\mathrm{a}}$ \\
\hline & 5 & $18.10 \pm 1.22^{\mathrm{c}}$ & $17.90 \pm 1.32^{\mathrm{c}}$ & $28.60 \pm 1.18^{b}$ & $35.80 \pm 1.22^{\mathrm{a}}$ \\
\hline & 10 & $16.00 \pm 1.28^{c}$ & $15.20 \pm 1.36^{\mathrm{c}}$ & $25.20 \pm 1.24^{\mathrm{b}}$ & $30.60 \pm 1.28^{\mathrm{a}}$ \\
\hline & 15 & $11.70 \pm 1.24^{\mathrm{c}}$ & $11.20 \pm 1.44^{\mathrm{c}}$ & $18.70 \pm 1.28^{\mathrm{b}}$ & $22.90 \pm 1.32^{\mathrm{a}}$ \\
\hline
\end{tabular}

* Values (means \pm SD) with different superscript letters are statistically significantly different $(P \leq 0.05)$. 
Effect of supplementation low fat probiotic yoghurt with pomegranate pomace powder on microbiological quality:

Table (5) showed that addition of PPP to reduced fat yoghurt increased the counts of total bacterial, and this increment was proportional to the supplementation ratio. With the storage period progressed the total bacterial count of all yoghurt treatments is increased.

Yeast and moulds could not be detected in all treatments up to 5 days of storage, and then appeared at 10 days of storage. Addition of PPP to low fat yoghurt treatments decreased yeast and moulds counts, and this decrement was proportional to the supplementation ratio. With the storage period progressed the yeast and mould counts of all yoghurt treatments were increased

Coliform bacteria could not be detected in all yoghurt treatments up to the end of storage period. These results have been confirmed by Elsanhoty et al, (2009) and Habib et al, ( 2018).

Addition of PPP to low fat yoghurt treatments increased the counts of Bifidobacterium. bifidum ,Streptococcus thermophiles and Lactobacillus acidophilus and this increment was proportional to the supplementation ratio. Streptococcus thermophiles and Lactobacillus acidophilus counts increased gradually in all treatments up to 10 days form storage and then decreased at the end of storage period. While Bifidobacterium bifidum counts decreased as storage period progressed.The addition of PPP improved the viability of probiotic starter culture. The current data align with Phuapaiboon et al. (2013), Elsanhoty and Ramadan, (2017) and Atwaa et al, 2020).

Effect of supplementation low fat probiotic yoghurt with pomegranate pomace powder on organoleptic characteristics:

From data presented in Table (6), it can be seen that, the lowest organoleptic characteristics scores was observed in control low fat yoghurt (C1), while adding PPP to low fat yoghurt enhanced its organoleptic properties and this enhancement was proportional to the supplementation ratio, low fat yoghurt enriched with 2\% PPP was similar to the control full fat yoghurt (3\% fat). The Organoleptic characteristics of all yoghurt treatments decreased as storage period progressed. Similar results were obtained by Alhamdani et al (2015) and Atwaa et al, (2020).

Table 5. Effect of supplementation low fat probiotic yoghurt with pomegranate pomace powder on microbiological quality during storage at refrigerator temperature for 15 day.

\begin{tabular}{|c|c|c|c|c|c|}
\hline \multirow{2}{*}{ Properties } & \multirow{2}{*}{ Treatments } & \multicolumn{4}{|c|}{ Storage period (days) } \\
\hline & & Fresh & 5 & 10 & 15 \\
\hline & $\mathrm{C}$ & 40 & 34 & 32 & 28 \\
\hline T.B.C & $\mathrm{C} 1$ & 51 & 45 & 41 & 37 \\
\hline \multirow[t]{2}{*}{$\mathrm{cfu} / 10^{7} \mathrm{~g}$} & $\mathrm{~T} 1$ & 55 & 51 & 44 & 40 \\
\hline & $\mathrm{T} 2$ & 62 & 54 & 50 & 44 \\
\hline \multirow{4}{*}{$\begin{array}{l}\text { Coliform } \\
\text { cfu/ } 10 \mathrm{~g}\end{array}$} & $\mathrm{C}$ & ND & ND & ND & ND \\
\hline & $\mathrm{C} 1$ & ND & ND & ND & ND \\
\hline & $\mathrm{T} 1$ & ND & ND & ND & ND \\
\hline & $\mathrm{T} 2$ & ND & $\mathrm{ND}$ & ND & ND \\
\hline \multirow{4}{*}{$\begin{array}{l}\text { Yeasts \& Moulds } \\
\text { cfu } / 10^{2} \mathrm{~g}\end{array}$} & $\mathrm{C}$ & ND & ND & 10 & 13 \\
\hline & $\mathrm{C} 1$ & ND & ND & 7 & 9 \\
\hline & $\mathrm{T} 1$ & ND & ND & 3 & 7 \\
\hline & $\mathrm{T} 2$ & ND & ND & 2 & 5 \\
\hline \multirow{4}{*}{$\begin{array}{l}\text { Streptococcus } \\
\text { thermophiles } \\
\text { cfu } / 10^{f} \mathrm{~g}\end{array}$} & $\mathrm{C}$ & 50 & 56 & 62 & 46 \\
\hline & $\mathrm{C} 1$ & 52 & 59 & 70 & 50 \\
\hline & $\mathrm{T} 1$ & 60 & 70 & 74 & 58 \\
\hline & $\mathrm{T} 2$ & 64 & 74 & 80 & 60 \\
\hline \multirow{4}{*}{$\begin{array}{l}\text { Lactobacillus } \\
\text { acidophilus } \\
\text { cfu } / 10^{7} \mathrm{~g}\end{array}$} & $\mathrm{C}$ & 40 & 44 & 48 & 35 \\
\hline & $\mathrm{C} 1$ & 48 & 52 & 56 & 42 \\
\hline & $\mathrm{T} 1$ & 60 & 66 & 70 & 55 \\
\hline & $\mathrm{T} 2$ & 66 & 71 & 76 & 60 \\
\hline \multirow{4}{*}{$\begin{array}{l}\text { Bifidobacterium. } \\
\text { bifidum } \\
\text { cfu } / 10^{7} \mathrm{~g}\end{array}$} & $\mathrm{C}$ & 42 & 35 & 30 & 26 \\
\hline & $\mathrm{C} 1$ & 45 & 32 & 21 & 20 \\
\hline & $\mathrm{T} 1$ & 53 & 41 & 40 & 33 \\
\hline & $\mathrm{T} 2$ & 59 & 50 & 44 & 36 \\
\hline
\end{tabular}

ND= not detected

Table 6. Organoleptic characteristics of low fat yoghurt supplemented with pomegranate pomace powder during storage at refrigerator temperature for 15 day

\begin{tabular}{|c|c|c|c|c|c|}
\hline \multirow{2}{*}{ Properties } & \multirow{2}{*}{$\begin{array}{c}\text { Storage period } \\
\text { (Day) }\end{array}$} & \multicolumn{4}{|c|}{ Treatments } \\
\hline & & $\mathrm{C}$ & $\mathrm{C}_{1}$ & $\mathrm{~T}_{1}$ & $\mathbf{T}_{2}$ \\
\hline \multirow{4}{*}{ Appearance } & Fresh & $9.30 \pm 0.22^{\mathrm{a}}$ & $7.50 \pm 0.32^{b}$ & $7.40 \pm 0.30^{b}$ & $7.00 \pm 0.28^{\mathrm{c}}$ \\
\hline & 5 & $9.00 \pm 0.28^{\mathrm{a}}$ & $7.20 \pm 0.36^{\mathrm{b}}$ & $7.00 \pm 0.35^{b}$ & $6.60 \pm 0.34^{\mathrm{c}}$ \\
\hline & 10 & $8.70 \pm 0.26^{\mathrm{a}}$ & $6.90 \pm 0.44^{b}$ & $6.70 \pm 0.28^{b}$ & $6.20 \pm 0.32^{c}$ \\
\hline & 15 & $8.40 \pm 0.32^{\mathrm{a}}$ & $6.50 \pm 0.52^{\mathrm{b}}$ & $6.30 \pm 0.20^{\mathrm{b}}$ & $6.00 \pm 0.25^{\mathrm{c}}$ \\
\hline \multirow{4}{*}{ Flavour } & Fresh & $8.60 \pm 0.18^{a}$ & $7.20 \pm 0.28^{\mathrm{d}}$ & $7.60 \pm 0.22^{\mathrm{c}}$ & $7.90 \pm 0.20^{\mathrm{b}}$ \\
\hline & 5 & $8.80 \pm 0.14^{\mathrm{a}}$ & $7.50 \pm 0.25^{\mathrm{d}}$ & $7.80 \pm 0.20^{c}$ & $8.20 \pm 0.18^{b}$ \\
\hline & 10 & $8.70 \pm 0.14^{\mathrm{a}}$ & $7.30 \pm 0.25^{\mathrm{d}}$ & $7.50 \pm 0.22^{\mathrm{c}}$ & $8.10 \pm 0.22^{b}$ \\
\hline & 15 & $8.40 \pm 0.20^{\mathrm{a}}$ & $7.00 \pm 0.30^{\mathrm{d}}$ & $7.20 \pm 0.28^{c}$ & $7.70 \pm 0.25^{b}$ \\
\hline \multirow{4}{*}{ Texture } & Fresh & $8.60 \pm 0.22^{\mathrm{a}}$ & $6.20 \pm 0.30^{\mathrm{d}}$ & $6.70 \pm 0.32^{\mathrm{c}}$ & $7.20 \pm 0.34^{b}$ \\
\hline & 5 & $8.20 \pm 0.26^{a}$ & $5.90 \pm 0.34^{\mathrm{d}}$ & $6.50 \pm 0.34^{c}$ & $7.00 \pm 0.33^{\mathrm{b}}$ \\
\hline & 10 & $7.90 \pm 0.30^{\mathrm{a}}$ & $5.70 \pm 0.40^{\mathrm{d}}$ & $6.20 \pm 0.38^{c}$ & $6.70 \pm 0.30^{b}$ \\
\hline & 15 & $7.60 \pm 0.32^{\mathrm{a}}$ & $5.40 \pm 0.36^{\mathrm{d}}$ & $5.80 \pm 0.36^{c}$ & $6.40 \pm 0.32^{b}$ \\
\hline \multirow{4}{*}{ Consistency } & Fresh & $8.10 \pm 0.22^{\mathrm{a}}$ & $5.90 \pm 0.30^{\mathrm{e}}$ & $6.30 \pm 0.26^{\mathrm{d}}$ & $7.30 \pm 0.22^{\mathrm{c}}$ \\
\hline & 5 & $7.80 \pm 0.24^{\mathrm{a}}$ & $5.60 \pm 0.32^{e}$ & $6.10 \pm 0.32^{\mathrm{d}}$ & $7.10 \pm 0.26^{\mathrm{c}}$ \\
\hline & 10 & $7.60 \pm 0.32^{\mathrm{a}}$ & $5.40 \pm 0.42^{\mathrm{e}}$ & $5.80 \pm 0.30^{\mathrm{d}}$ & $6.80 \pm 0.33^{c}$ \\
\hline & 15 & $7.30 \pm 0.30^{\mathrm{a}}$ & $5.30 \pm 0.40^{\mathrm{e}}$ & $5.60 \pm 0.33^{d}$ & $6.60 \pm 0.30^{c}$ \\
\hline \multirow{4}{*}{$\begin{array}{l}\text { Overall } \\
\text { acceptability }\end{array}$} & Fresh & $8.70 \pm 0.22^{\mathrm{a}}$ & $5.90 \pm 0.28^{d}$ & $6.70 \pm 0.28^{c}$ & $7.90 \pm 0.24^{b}$ \\
\hline & 5 & $8.50 \pm 0.28^{\mathrm{a}}$ & $5.60 \pm 0.33^{d}$ & $6.40 \pm 0.25^{\mathrm{c}}$ & $7.70 \pm 0.28^{b}$ \\
\hline & 10 & $8.40 \pm 0.30^{\mathrm{a}}$ & $5.40 \pm 0.35^{\mathrm{d}}$ & $6.20 \pm 0.32^{c}$ & $7.40 \pm 0.30^{\mathrm{b}}$ \\
\hline & 15 & $8.20 \pm 0.32^{\mathrm{a}}$ & $5.20 \pm 0.32^{\mathrm{d}}$ & $6.00 \pm 0.30^{c}$ & $7.30 \pm 0.32^{\mathrm{b}}$ \\
\hline
\end{tabular}

* Values (means \pm SD) with different superscript letters are statistically significantly different $(P \leq 0.05)$.

\section{CONCLUSION}

Pomegranate pomace powder having a high content of phenolic component and dietary fiber. Therefore, pomegranate pomace powder could be used as a source of bioactive components and dietary fiber in manufacture of low fat yoghurt which enhanced its nutritional, chemical, rheological, microbiological, antioxidant and sensory characteristics.

\section{REFERENCES}

Akhtar, S., Ismail T., Atukorala, S., and Arlappa, N. (2013): Micronutrients deficiencies in South Asia- current status and strategies. Trends Food Sci Technol 31:55-62. 
Akhtar, S., Ismail, T., Fraternale, D., and Sestili, P. (2015). Pomegranate peel and peel extracts: chemistry and food features. Food Chem, 174:417-425.

Al-hamdani, .M.S., Al-Anbary, E.H., and Ahmed, .M.(2015). Effect of Lupin (Lupinus albifrons) flour on microbial and sensory properties of local Yoghurt. Advances in Life Science and Technology, 34.1-6.

AOAC. (2007). Association of official analytical chemists official method of analysis.(18th Ed.), Benjamin Franklin Station Washington, D.C., USA

AOAC. (2016). Official Methods of Analysis of the Association of Official Analytical Chemists, 20th ed, Arligton, Virginia, USA.

Arora, S.K., Patell, A.A., and Chauhan, O.P. (2015). Trends in Milk and Milk Products Fortification with Dietary Fibers. American Journal of Advanced Food Science and Technology . 3 ( 1) : 14-27.

Aryana, K.J. (2003). Folic acid fortified fat free plain set yoghurts. Int. J. Dairy Technol., 56(4) : 219-222.

Atwaa, E.H., Eman T. Abou Sayed-Ahmed and Hassan, M. A. A.(2020).Physicochemical, Microbiological and Sensory Properties of Low Fat Probiotic Yoghurt Fortified with Mango Pulp Fiber Waste as Source of Dietary Fiber. Journal of Food and Dairy Sciences.11, 9, : 271-276

Baú; T.R., Sandra Garcia and Elza Iouko Ida.(2014).Evaluation of a functional soy product with addition of soy fiber and fermented with probiotic kefir culture.Braz. Arch. Biol. Technol,.57 (3): 402-409.

Brand-Williams, W.; Cuvelier, M. E.; and Berset, C.(1995). Use of a Free Radical Method to Evaluate Antioxidant Activity. Lebenson Wiss Technol., 28, 25-30.

Cano-Lamadrid, M., Lech, K.,Calın-Sanchez, A.,Ema C. RosasBurgos., Figiel, A.,Aneta Wojdyło.,Wasilewska, M. and Carbonell-Barrachina, A.A.(2018).Quality of pomegranate pomace as affected by drying method .J Food Sci Technol , 55(3):1074-1082.

Dabija, A., Codinăa, G.G., Gâtlana, A.M., and Rusu, L.(2018). Quality assessment of yogurt enriched with different types of fibers. Cyta - Journal of Food. 16, 1, 859-867.

Elsanhoty, R., Zaghlol, A., and Hassanein, A. (2009): The manufacture of low fat labneh containing barely betaGlucan 1-Chememical composition, microbiological evaluation and sensory properties. Current Research in Dairy Sciences 1, 1-12.

Elsanhoty, R.M., and Ramadan, M.F.(2018). Changes in the physicochemical and microbiological properties of probioticfermented low-fat yoghurt enriched with barley $\beta$-glucan during cold storage. Mljekarstvo, 68 (4), 295-309.

Gullon, B., Pinatado, M.E., Perez-Alvarez, J.A., and ViudaMartos, M. (2016).Assessment of polyphenolic profile and antibacterial activity of pomegranate peel (Punica granatum L.) flour obtained from by-product of juice extraction. Food Control 59:94-98.

Habib, E.E., Shamsia, S.M., Awad, S.A., and Ziena, H.M. (2018) Physicochemical and Sensory Properties of Labneh Fortified with Salvia Officinalis. Alexandria Science Exchange Journal, 38, 4 761-769.
Hasani , S., Sari, A.A.,Heshmati, A., and Karami, M.(2017). Physicochemical and sensory attributes assessment of functional low-fat yogurt produced by incorporation of barley bran and Lactobacillus acidophilus .Food Sci. Nutr. , 5:875-880

Hasnaoui, N., Wathelet, B., and Jime'nez-Araujo, A. (2014). Valorization of pomegranate peel from 12 cultivars: dietary fibre composition, antioxidant capacity and functional properties. Food Chem, 160:196-203.

Houghtby, G.A., Matuin, L.J., and Koenig, E.K. (1992). Microbiological count methods. In: Standard methods for the examination of dairy products Marshall, T.R. (Editor) American Public Health Association, Washington, DC., USA

Jambi, H.A.(2018). Evaluation of physio-chemical and sensory properties of yogurt prepared with date pits powder. Current Science International,7 (1) :1-9.

Kang, J.H., and Song K.B. (2017). Effect of pomegranate (Punica granatum L.) pomace extract as a washing agent on the inactivation of Listeria monocytogenes inoculated on fresh produce. Int J Food Sci Technol., 52(10):22952302.

Kaur, C.; and Kapoor, H. C.(2002). Antioxidant Activity and Total Phenolic Content of Some Asian Vegetables. Int. J. Food Sci. Tech., 37, 153-161.

Marshall R.T.( 1992). Standard Methods for the Examination of Dairy Products. 16th edit. American Public Health Association (APHA), Washington, D.C. USA. p. 158.

Martin -Diana, A.B., Janer, C., and Requena, T. (2003) .Development of a fermented goat's milk containing probiotic bacteria. Inter. Dairy J., 13: 827-833.

McClave, J.T., and Benson, P. G.(1991). Statistical for business and economics. Max Well Macmillan International editions. Dellen Publishing Co. USA. 1991:272-295.

Nelson, J.A., and Trout, G.H.(1981). Judging of dairy products, 4th Ed. INC Westport, Academic Press. 345-567.

Ozer, B., Kirmaci, H.A., Oztekin, S., Hayaloglu, A., and Atamer, M .(2007) Incorporation of microbial transglutaminase into non-fat yogurt production. Int Dairy J 17:199-207.

Pakseresht, S., Tehrani, M.M., and Razavi, S.M.A.(2019).Optimization of low-fat set-type yoghurt: effect of altered whey protein to casein ratio, fat content and microbial transglutaminase on rheological and sensorial properties.J Food Sci Technol , 54(8):2351-2360.

Phuapaiboon, P., Leenanon, B., and Levin, R.E. (2013): Effect of Lactococcus lactis immobilized within pineapple and yam bean segments, and Jerusalem Artichoke powder on its viability and quality of Yoghurt. Food and Bioprocess Technology 6, 2751-2762.

Ramchandran, L, and Shah, N.P. (2008). Effect of addition of versa gel on microbial, chemical, and physical properties of low-fat yoghurt. J Food Sci 73:360-367.

Sagar ,N.A., Pareek ,S., Sharma,S., , Yahia, E.M., and Lobo ,M.G.(2018). Fruit and Vegetable Waste: Bioactive Compounds, Their Extraction, and Possible Utilization. Comprehensive Reviews in Food Science and Food Safety.17 (3):512-531.

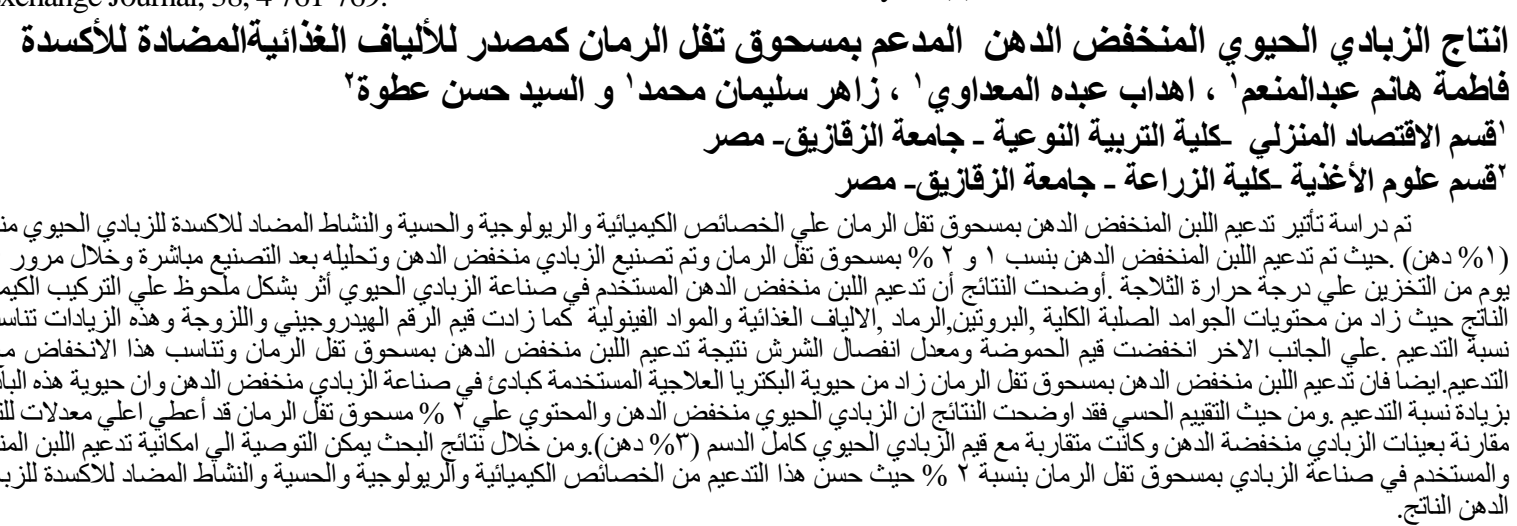

